\title{
POLITICAL IDENTITY: EXPERIMENTAL EVIDENCE ON ANTI-AMERICANISM IN PAKISTAN
}

\author{
Leonardo Bursztyn \\ University of Chicago
}

\section{Bruno Ferman}

Sao Paulo School of Economics - FGV

\section{Ali Hasanain}

Lahore University of Management

Sciences

\author{
Michael Callen \\ UC San Diego
}

Saad Gulzar

Stanford University

Noam Yuchtman

London School of Economics

\begin{abstract}
We identify Pakistani men's willingness to pay to preserve their anti-American identity using two experiments imposing clearly-specified financial costs on anti-American expression, with minimal consequential or social considerations. In two distinct studies, one-quarter to one-third of subjects forgo payments from the U.S. government worth around one-fifth of a day's wage to avoid an identitythreatening choice: anonymously checking a box indicating gratitude toward the U.S. government. We find sensitivity to both payment size and anticipated social context: when subjects anticipate that rejection will be observable by others, rejection falls suggesting that, for some, social image can outweigh self-image. Change () to curly brakets around line 124-130 (JEL: P16, D03, C90)
\end{abstract}

The editor in charge of this paper was Paola Giuliano.

Acknowledgments: We would like to thank the Editor (Paola Giuliano), three anonymous referees, Roland Bénabou, Chris Blattman, Sylvain Chassang, Ernesto Dal Bó, Stefano DellaVigna, Lena Edlund, Fred Finan, Ray Fisman, Macartan Humphreys, Matthew Kahn, Ethan Kaplan, Dean Karlan, Asim Ijaz Khwaja, Jennifer Lerner, David Levine, Aprajit Mahajan, Ted Miguel, Rohini Pande, Petra Persson, Torsten Persson, Daniel Posner, Jacob Shapiro, Jesse Shapiro, Nico Voigtländer, Romain Wacziarg, Reed Walker, and numerous seminar participants for helpful comments and suggestions. Sarah Brierley and Usman Naeem provided excellent research assistance. We thank the Center for Global Management at UCLA Anderson for financial support.

E-mail: bursztyn@uchicago.edu (Bursztyn); mjcallen@ucsd.edu (Callen); bruno.ferman@fgv.br (Ferman); gulzar@stanford.edu (Gulzar); hasanain@lums.edu.pk (Hasanain); n.yuchtman@1se.ac.uk (Yuchtman) 


\section{Introduction}

Political identity appears to be at the root of a wide range of political behavior, most strikingly when individuals take actions seemingly opposed to their material selfinterest. ${ }^{1}$ Yet, the existence of political identity is difficult to establish. Consider a low income voter's opposition to redistribution: this could be due to consequential motives, such as holding particular beliefs about outcomes (correct or incorrect); to social considerations; or, to the preservation of her sense of self. ${ }^{2}$

In this paper, we aim to isolate identity's role in political behavior, separating it from consequential or social motives. This represents an empirical challenge: on the one hand, identifying individuals for whom identity drives political expression requires the study of behavior in a context in which one is certain that the private cost of expression exceeds any anticipated consequential or social benefits. On the other hand, such behavior may be difficult to interpret if behavior is distorted by the awareness that choices are being studied by the experimenter or due to the artificiality of the setting and action. This tension is visible in existing empirical work: for example, Kamenica and Brad (2014) sharply test for intrinsic (expressive) motives for voting behavior, but do so in a lab setting with student subjects, using direct elicitation. In contrast, the famous "lost letter" methodology (Milgram 1977) elicits attitudes indirectly, but cannot isolate intrinsic motives for holding particular attitudes.

We study Pakistani men's willingness to pay to preserve their anti-American identity. This represents an ideal setting for the study of political identity: not only is identity often built upon one's affiliation with one group (and non-affiliation with another), but also anti-Americanism (whether driven by identity or other motives) in Pakistan and the Islamic World more broadly, is of great policy relevance (Blaydes and Linzer 2012). Even within this setting, it is difficult to determine the extent to which anti-Americanism is motivated by identity considerations; it may, instead, be driven primarily by consequential or social concerns. Indeed, U.S. policy has a profound impact on Pakistani people's lives, from drone strikes to humanitarian aid (which is broadly viewed as affecting domestic Pakistani politics). Social networks and social pressure might play an important role in coordinating behavior. We both identify individuals with anti-American identities, and also study the economics of the expression of identity-driven anti-Americanism, examining how it responds to changes in the private financial cost and in social context.

1. We conceive of identity-motivated behavior following Akerlof and Kranton (2000), who note that individuals may choose to engage in a costly action solely to preserve their "sense of self", even when they fully understand that the action has no consequence and is undertaken in private.

2. Relevant beliefs include the causes of individual success (Bénabou and Tirole 2006a). Mistakes regarding payoffs may arise from particular issues being more salient than others; for example, a voter may ignore redistribution while focusing on cultural issues (see Bordalo et al. 2013 for a model of salience shaping consumer choice). Social pressure shaping political expression has been studied by DellaVigna et al. (2016), among others. Shayo (2009) provides a theoretical analysis and cross-country data suggesting the important role of identity in shaping redistribution policies. 
We present evidence from two experiments in which we use a novel design to identify identity-motivated, political expression. We minimize instrumental and social incentives for political expression, and elicit political attitudes in an indirect manner to reduce concerns about unnatural behavior or experimenter demand effects. ${ }^{3}$ Our experimental designs allow us to study how self-image expression responds to changed economic incentives - both financial costs and the social context in which expression occurs-and to correlate our measure of political identity with relevant, real-world political behavior.

Our first experiment implementing our methodology ("Experiment 1") was conducted in Pakistan in July, 2013, with 1,152 participants. During each experimental session, groups of Pakistani men, aged between 18 and 35, were brought into a room where they were asked to complete a standard "Big Five" personality survey. The intervention of interest occurred after subjects had completed the survey, though subjects were unaware of this fact. In return for completing the survey, study participants were offered a "bonus" payment (above a show-up fee they had received upon arrival). Receiving the bonus payment required checking a box in a form that indicated (from the subject's perspective): "I gratefully thank the [funding agency] for its generosity and I accept the bonus payment offer." Rejecting the payment required checking a box in the same form that indicated (again, from the subject's perspective): "I choose not to accept the bonus payment offer." The experiment randomly varied three separate components of the form, at the individual level, in a $2 \times 2 \times 2$ design:

The Identity of the Funding Agency. The funding agency was either the U.S. government or the Lahore University of Management Sciences (LUMS), a leading Pakistani university. ${ }^{4}$

The Expectation of Privacy. Subjects were led to believe that their bonus payment acceptance decision would be observed by other experimental participants, or would be completely private. ${ }^{5}$

The Amount of Money Offered. Subjects were either offered a bonus payment of 100 Pakistani Rupees (Rs.) or of 500 Rs. Both payments represented a sizable fraction of a day's wage (the daily wage for a manual worker in 2013 was roughly 400-500 Rs.).

We conceptualize the choice to reject payment as being driven by three primary considerations (see Section 4 for further detail). First, subjects might choose to reject payment, particularly from the U.S. government, taking into account real world

3. Social psychologists have long been aware of problems created by experimenter demand effects (Rosenthal 1963, 1966). Reflecting this, many studies in social psychology make use of indirect elicitation in part to avoid experimenter demand effects (e.g., Cohen et al. 1996).

4. Funds for bonus payments in fact came from the (public, so government-funded) University of California or from LUMS.

5. Manipulation of expectations of privacy follows a similar design to Bursztyn and Jensen (2015). 
consequences of their choices. In our experiment, this "instrumental" determinant of political expression is practically shut down, since accepting or rejecting the money offer is likely to have only a trivial real-world impact. Second, subjects' choices might be shaped by social concerns. In the "private" condition, subjects' anonymity practically eliminates social incentives to reject payment. Finally, we expect that subjects with anti-American political identities will have their self-images threatened by the act of expressing gratitude to the U.S. government; this might lead to rejection of the offer even in the absence of consequential or social concerns. Thus, rejection of the U.S. government payment offer in the private condition is our indicator of antiAmerican political identity.

Subjects may wish to reject payment for reasons other than anti-Americanism, for example, because they do not want to feel indebted to another party. We thus compare subjects' rates of rejecting money from the U.S. government to rates of rejecting money from LUMS in order to "difference out" a propensity to reject bonus payments from a relatively neutral funder. We also use experimental variation in the expected social visibility of the rejection decision, and in an individual's private financial cost of rejecting the U.S. government offer, to estimate the roles of social and financial incentives in an individual's expression of their (anti-American) identity.

A virtue of our design is our ability to elicit individuals' identity-driven views in a setting in which subjects' awareness of the elicitation is significantly reduced compared to more direct methods of eliciting political attitudes. ${ }^{6}$ Not only was no subject aware of the purpose of the study, but also, the action through which individuals' preferences were revealed appeared, from the subjects' perspective, simply to be part of the process of receiving payment for completing the survey. Because the choice of whether to accept the bonus payment does not appear to be of scientific interest to the researcher, we are able to observe subjects' (relatively) natural behavior, reducing concerns about experimenter demand effects or Hawthorne effects.

We find that when individuals act privately, a significant minority-around one quarter of subjects - are willing to forgo 100 Rs. to avoid taking an action that would undermine their self-image: checking a box and thus thanking the U.S. government for its generosity.

It is not obvious ex ante what will be the effects of leading subjects to believe that their decision to accept the payment will be observed by the other study participants. On the one hand, in a context in which some individuals have strongly-held antiAmerican identities, it is plausible that "moderate" subjects (i.e., those who accept the payment in private) may feel pressure to reject the payment offer. On the other hand, because those with anti-American identities are a minority, it is conceivable that they will wish to conform to the majority around them, making them more likely to accept the payment offer. In fact, we find that when subjects anticipate that their behavior will be public, significantly fewer individuals reject the bonus payment- the

6. The influence of the experimenter on subjects' behavior has been shown, e.g., in Hoffman et al. (1996). 
rejection rate falls by nearly 10 percentage points. ${ }^{7}$ This suggests that in our context, a desire to conform to the majority behavior dominates any anticipated pressure from anti-American individuals. This finding is not obvious: a subset of anti-American individuals with strong self-image concerns exhibit social image concerns that work in the opposite direction.

Next, we find that individuals' willingness to check the box thanking the U.S. government is responsive to the size of the payment. While $25 \%$ of subjects are willing to forgo a 100 Rs. payment rather than check the box indicating gratitude toward the U.S., only around $10 \%$ of subjects are willing to forgo a 500 Rs. payment (this difference is highly statistically significant). Thus, even among individuals with deeply-held political identity (i.e., willing to give up a quarter of a day's wage rather than check the box to accept payment), there is a "downward-sloping demand curve" for the preservation of political identity.

Our second experiment ("Experiment 2") was conducted with 1,991 subjects recruited from the area around Lahore, Pakistan, in September and October, 2015. Rather than recruit subjects into a lab-like setting, we simplified our methodology to allow us to identify anti-American identity at subjects' homes, using standard household survey methods (requiring an Android tablet). Subjects were asked to privately complete a 10-question personality survey on the tablet; then, analogous to our first experiment, subjects were offered a 100 Rs. bonus payment paid for by the U.S. government. Using the same language as in the first experiment, subjects needed to indicate gratitude to the U.S. government to receive the payment. Importantly, subjects were provided with "cover" for their choice of whether to accept the payment: although experimenters paid them directly, payment included a random component, so experimenters did not know whether subjects accepted the bonus payment offer. Using a different technology, a different subject pool, drawn from a different part of Pakistan, we find a rejection rate of $34 \%$ - a similar rejection rate to what we found in the first experiment. This indicates that our findings in Experiment 1 have a degree of external validity and robustness. In addition to this replication exercise, our second experiment allows us to examine whether our measure of political attitudes is correlated with realworld political behavior of interest.

We interpret our findings using a conceptual framework that clarifies threats to our interpretation of rejection of the U.S. bonus payment offer as an expression of political identity. In particular, in Section 4 we explore: (i) consequential motives for rejecting payment; (ii) social motives for rejecting payment; and, (iii) intrinsic motives for rejecting payment other than anti-American political identity. Regarding consequential motives for rejection, the stakes are small, and subjects are unlikely to view their choices as affecting any important policy choices. Regarding social

7. In our analysis below, we present results comparing rejection rates for the U.S. government vs. LUMS as the funding agency. The results are very similar to the raw rejection rates presented here. By differencing out LUMS rejection rates across conditions we account for rejection for reasons other than anti-Americanism and for other sources of private/public differences in rejection rates. In fact, LUMS rejection rates are slightly (insignificantly) higher in the public condition than in the private condition. 
concerns, we note that experimenter demand effects (active in both Experiment 1 and Experiment 2) would tend to pull subjects toward accepting payment. In addition, public expression in our first experiment was more moderate suggesting that, if there were social concerns in the private condition, they would work toward finding fewer individuals rejecting payments from the U.S. government. To rule out a range of possible intrinsic motives to reject payment (e.g., social norms regarding accepting payments), in Experiment 1, we difference out rejection of payment offers from LUMS; this does not meaningfully affect our conclusions. In addition, responses to direct survey questions, administered following our main intervention in Experiment 1, support our interpretation of rejection of payment from the U.S. government as an expression of a political identity oppositional to the U.S. government. We find that individuals who rejected the U.S. bonus payment report significantly more negative views of the U.S. government, while individuals who rejected the U.S. payment offer are no more likely to report negative views of the government of Japan.

Our work contributes to four broad literatures. First, and most directly, we contribute to a large literature on individuals' decisions to engage in political behavior. Economists have typically focused on instrumental or consequential motives: for example, in the pivotal voter model, individuals vote to (probabilistically) change electoral outcomes and thus policy. ${ }^{8}$ More recently economists have studied the role of social incentives in political behavior. ${ }^{9}$ Our study contributes evidence on the much less well understood role of intrinsic utility stemming from one's political identity. ${ }^{10}$

Second, our work contributes to a growing empirical literature on intrinsic, extrinsic, and social motives for a range of behavior. ${ }^{11}$ We contribute to this literature by being the first to isolate an intrinsic, identity-motivated political preference that individuals are willing to pay a cost to express.

8. See Downs (1957), Palfrey and Rosenthal (1983), Ledyard (1984), and Palfrey and Rosenthal (1985).

9. Social incentives may operate through a desire to conform (Bernheim 1994), through a desire to send a signal to a particular group, or through the utility derived from social activity. This is true even of the (likely) inconsequential, (often) private act of voting (Gerber et al. 2008, Funk 2010, DellaVigna et al. 2016, and Gerber et al. 2013).

10. Expressive voting models, by highlighting non-consequential motives for voting, are closely related (see Riker and Ordeshook 1968, Brennan and Buchanan 1984, Brennan and Lomasky 1993, Scheussler 2000, Feddersen and Sandroni 2006).

11. Intrinsic motivations for a range of behaviors have long received attention among economists, from the study of taste-based discrimination (Becker 1957), to the important role played by identity in shaping economic and social choices (Akerlof and Kranton 2000) to individuals' response to incentives (Bénabou and Tirole 2003) to altruism (Andreoni 1990). Recent empirical work on intrinsic and social motives for behavior include DellaVigna et al. (2012), who use a field experiment to test for altruism and social pressure in charitable giving; Ariely et al. (2009), who experimentally evaluate whether larger monetary incentives crowd out social incentives for pro-social behavior, thus testing the theory in Bénabou and Tirole (2006b); Rao (2019), who measures the extent to which students from elite Indian schools are willing to pay a cost to avoid being paired with lower income students in a sports competition; and, Augenblick et al. (2012), who conduct an experiment eliciting the beliefs of individuals belonging to an apocalyptic religious group in an incentivized manner. 
Third, our experiments contribute to a growing literature on the measurement of sensitive attitudes. ${ }^{12}$ While methods such as list experiments allow for the measurement of political attitudes at the group level, our methodology uses indirect elicitation to identify (revealed) political preferences at the individual level. Indeed, a goal of Experiment 2 was to adapt the revealed preference laboratory measure of political attitudes to field implementation. Recently, recognizing that more than half of the world's poor now live in fragile states, a growing literature focuses on whether aid can reduce instability by increasing popular support for the government (Beath et al. 2012; Berman et al. 2011, 2017; Dell and Querubin 2017; Jha and Shayo 2017). Views of the government are likely to be particularly sensitive in such a context, making directly elicited survey responses suspect. Our method can provide an individual-level revealed preference approach to studying whether development aid and government policy affect sensitive political beliefs.

Finally, our findings contribute to a growing body of empirical evidence on, and economic analysis of, social and political outcomes in South Asia, an area of geopolitical importance. ${ }^{13}$ We show that a substantial minority of Pakistani men in our two experimental samples are anti-American for intrinsic reasons. We find that some individuals with strongly-held ideological views will suppress the expression of those views when the financial costs or anticipated social costs of expression are high enough. However, the existence of intrinsically-motivated anti-Americanism suggests that there are limits to the effects of policies focused on reducing anti-American political expression simply by changing financial or social incentives.

The remainder of the paper is as follows: in Section 2, we describe the implementation of, and the results from, Experiment 1. In Section 3, we discuss Experiment 2. In Section 4, we discuss threats to our interpretation of rejection of the U.S. bonus payment offer as an expression of political identity. In Section 5 we offer concluding thoughts.

12. Warner (1965) introduced the "randomized response technique", Raghavarao and Federer (1979) formalized the "list experiment" (also called the "unmatched count" and the "item count technique"), and Sniderman and Piazza (1993) provide, to our knowledge, the first example of an endorsement experiment.

13. Clingingsmith et al. (2009) study the impact of the Hajj pilgrimage on a broad range of attitudes among Pakistanis. Beath et al. (2012) study the impact of foreign aid on Afghans' views on security and on the Afghan government, NGO's and foreign military forces. Delavande and Zafar (2012) experimentally analyze how Pakistanis' attitudes towards the U.S. are affected by provision of information about the U.S. Outside of South Asia, Corstange (2014) finds that foreign sponsorship of a survey systematically affects response rates in Lebanon. See Gentzkow and Shapiro (2004) for an overview of anti-Americanism in the Islamic world. 


\section{Experiment 1}

\subsection{Design and Implementation}

2.1.1. Timeline and Site Selection. Following a set of small pilot studies that served as a "proof of concept" that our design could be implemented safely and successfully (described in Appendix Section A1), we implemented Experiment 1 simultaneously in three cities, Peshawar, Islamabad, and Dera Ghazi Khan, between July 7th and July 16th, 2013 (Figure A.1, in Appendix A2, presents a map of the laboratory locations). One objective of our project was to measure the degree of anti-Americanism among populations directly affected by the "war on terror" - this is where anti-American views are likely to be of greatest importance. To access these populations, we ran our experiment in areas either directly affected by the United States-led invasion of Afghanistan (Peshawar) or in cities that have substantial numbers of refugees from conflict-affected areas (Islamabad and Dera Ghazi Khan).

2.1.2. Subject Recruitment and Screening. We contracted with local survey firms no Westerners were directly involved in implementation of the study - to recruit men aged between 18 and 35 from neighborhoods with large migrant populations in Islamabad and Peshawar. In both cities, we asked the recruiters to target migrants from the Federally Administered Tribal Areas (FATA), Khyber Pakthunhwa (KP), and Balochistan. ${ }^{14}$ In Dera Ghazi Khan, we first selected a tehsil randomly, then selected a union council randomly, and then used a simple right-hand sampling rule to contact potential participants. We ran 22 sessions in Peshawar, 10 sessions in Islamabad, and 16 sessions in Dera Ghazi Khan.

Upon contacting a potential subject, recruiters asked him to read aloud a short script in order to verify literacy, and an additional literacy test of comparable difficulty was administered when a subject reached the study site. Potential subjects who failed either test where not allowed to participate. Subject literacy was crucial for our experimental design, as the entire study required subjects to comprehend printed text. Appendix A2, Figure A.2, provides Urdu translations of the two literacy screening tasks and English translations of both literacy test scripts are reproduced in Appendix A3.

2.1.3. Enrollment. After subjects arrived at the study site, they were directed to a waiting room, provided with an informed consent form to read, and asked to wait until they were called to participate. We relied on verbal informed consent to assure subjects that personally-identifiable information on their participation and choices was not being collected (the consent protocol is provided in Appendix A3). The study coordinator called subjects to enroll one at a time; subjects then received a chit with

14. While we did not record the birth place of subjects to preserve anonymity, in these cities our recruiters drew subjects from neighborhoods primarily populated by migrants from the Swat and Malakand agencies (agencies are administrative units in FATA). Both of these agencies, located in FATA, have seen substantial levels of insurgent conflict in recent years. 
a randomly assigned subject number, between 1 and 24, from a research assistant. ${ }^{15}$ After receiving their number, subjects then went to the enrollment desk outside of the laboratory (Appendix A2, Figure A.3, provides a picture of the enrollment desk). At the desk, subjects read the second literacy script aloud, and received a payment envelope with their subject number printed on it. ${ }^{16}$ After completing the enrollment procedure, a research assistant led subjects into the laboratory and seated them at the individual lab station corresponding to their subject number.

Lab stations consisted of a chair with a clipboard; laboratory materials were placed on the chairs, which were positioned approximately four feet apart to prevent subjects from observing each other's choices (in Appendix A2, Figure A.4 provides a picture of the experiment site in Islamabad and Figure A.5 provides a picture of the experiment site in Peshawar). We randomly assigned survey versions to lab station numbers using a simple computer program (Appendix A2, Figure A.6, provides the mapping between survey versions and lab stations). All sessions involved exactly 24 subjects, resulting in a total of 1,152 men participating in the main study. After a session, research assistants ensured that subjects exited the building; they were bussed off site immediately and were not allowed to interact with other subjects waiting to participate in the study.

2.1.4. The Experiment. At the beginning of a session, the lab director read a set of instructions aloud, explaining the laboratory protocol, and talking subjects through four specific example questions (instructions are provided in Appendix A3). Each subject had a printed version of these questions, which were intended to familiarize subjects with the kinds of multiple choice questions they would have to answer in activity 1 (a personality survey). Importantly, these instructions were not linked to politics or ideology. After completing the instructions, the lab director took questions. The director then indicated that no further questions would be answered during the study, allowing subjects one final opportunity to ask questions before the experiment commenced. It is important to emphasize that no details were provided by the lab director regarding the payment process; research assistants were told to reveal no more than that payment for completing the study would occur at the end of the session. To increase subjects' confidence that they would be paid, subjects were provided their show-up fee of 300 Rs. when they began the first activity in the study.

The experiment involved four separate activities, each of which required completing a form contained in a separate envelope, numbered in order. These materials are reproduced completely in Appendix A3. Upon completion of an activity, subjects were instructed to close their envelope and place it below their chair

15. Individual stations were ordered sequentially by subject number inside the lab. Subject numbers were provided in random order to reduce the chance that subjects would be acquainted with the person sitting next to them-a concern if acquainted subjects entered the study site together, and station assignments were made in a non-random order. In practice, a research assistant handed each subject a chit, numbered from 1 to 24 , from a shuffled deck. The number on the chit became a subject's participant identification number.

16. Only one potential subject passed the first reading comprehension test but failed the second; this subject was replaced from the pool of recruits. 
before proceeding. Furthermore, they were told not to return to previously completed activities, and that subjects who did not comply would be asked to leave. The primary purpose of strictly disallowing participants from returning to previous activities was to ensure that they could not change their responses in the revealed preference activity (activity 2) after completing the stated preference activity (activity 4).

When all subjects had completed the four activities, the lab director and research assistant collected all laboratory materials except for subjects' chits, which subjects had received upon enrollment. The envelopes (on which were written subjects' participant identification numbers) were taken into a separate room with the laboratory materials for the calculation of payments for each subject. Payments were placed in envelopes, which were then exchanged for the chits handed out to subjects at the beginning of the session.

Activity 1. The experiment began as a standard personality survey which was contained in envelope 1 along with subjects' "show up" payment. In addition to a few demographic questions, participants completed a Big 5 personality assessment. The version of the Big 5 assessment used by our team was adapted to use in Pakistan and validated by psychologists at the National Institute of Psychology at Quaid-i-Azam University.

Activity 2. After completing the survey, subjects opened the second envelope. This envelope contained an offer of an additional payment (above that for showing up) in return for checking a box on a letter to the funding agency. Checking the box indicated acceptance of the payment and gratitude to the agency for providing funding. This activity measures whether respondents are differentially willing to forgo a payment, depending on the funder (U.S. government or the Lahore University of Management Sciences), the amount of the payment (100 Rs. or 500 Rs. ), and respondents' perception of whether the payment would be public or private. Specifically, envelope 2 contained a piece of paper with the following information printed on it (italics indicate text that varied depending on the experimental condition, with slashes dividing the conditions):

"Thank you for completing the survey. In return for completing the survey, we can offer you a bonus payment. Funding for the bonus payment comes from \{Lahore University of Management Sciences / the U.S. government $\}$. We can pay you $\{100$ Rs. / 500 Rs. $\}$ for completing the survey, but in order to receive the bonus payment you are required to acknowledge receipt of the funds provided by \{Lahore University of Management Sciences / the U.S. government $\}$ and thank the funder. If you choose not to accept the payment, you will forgo the bonus payment of $\{100$ Rs. $/ 500 R s$. $\}$, but not the payment of 300 Rs. for your participation."

After this passage, in half of the forms, the language emphasized that subjects' choices would be private, while in the other half, the language implied that subjects' choices to accept the bonus payment would be observed by other subjects, as follows: 
"If you choose to accept the bonus payment, $\{\varnothing /$ your decision will be private; $\}$ in order to receive this additional payment, \{you will be asked to turn the letter in to the survey coordinator in the front of the room, so other participants will see you turn in the letter / you will simply replace the letter in envelope 2 and submit it with your other survey materials at the end of the study, so no other participants will know your choice . Once you have made your decision on the next page, please place the letter into envelope 2 , whether or not you chose to accept the bonus payment."

In addition to the sheet of paper with instructions, envelope 2 contained the bonus payment acceptance/rejection letter, with the following options:

I gratefully thank Lahore University of Management Sciences / the U.S. government $\}$ for its generosity and I accept the bonus payment offer.

I choose not to accept the bonus payment offer.

It is worth noting that to ensure the safety of participants, in practice, no subject's choice of whether to accept the bonus payment was actually public. All participants turned their acceptance/rejection letter in to the survey coordinator at the front of the room, having replaced their letter into envelope 2, and submitting it with the other survey materials (note that we aimed to minimize the use of deception by not providing false information about what would be required of participants, as the language in both "public" and "private" conditions was literally true). The language in the "public" treatment arm was designed to suggest that the decision to accept the bonus payment would not be private, but subjects in the "public" condition still may have expected their decision to be private because they knew that the letter would be enclosed in an envelope. Because we can only imperfectly manipulate expectations of privacy, we view this exercise as providing a lower bound estimate of the effect of making the decision to accept the bonus payment public.

Activity 3. In activity 3, participants filled out a self-response survey that began by asking subjects to guess how many of the other participants where willing to accept the bonus payment. This question was incentivized: subjects were informed that the three individuals who guessed closest to the actual number would receive an additional 300 Rs. Next, the survey collected information on the number of other participants the respondent knew. We then ran a "list experiment," a method used to measure grouplevel attitudes toward sensitive topics. The two sensitive topics selected were closely related to the political identity we study: "refusing humanitarian aid from the U.S. government" and "supporting the activities of Pakistan Tehreek-e-Insaf (PTI)", the most anti-American of the major political parties in Pakistan.

Activity 4. Envelope 4 contained another survey, which asked subjects direct questions to elicit their stated preference support for: (i) aid provided by the Japanese government to Pakistan; (ii) the Japanese government overall; (iii) aid provided by the 
United States; and (iv) the United States government overall. We also asked a question regarding willingness to take risk using a simple Likert scale approach; we asked about subjects' political awareness; and, about their support for Japan and the U.S. relative to other subjects in the room.

Payments. When all subjects had completed the survey, they were asked to come, in order of their subject number, to the front of the room. They gave their payment envelope and materials packet to the session coordinator and were asked to return to their seat to await payment. After collecting all 24 packets, two research assistants calculated total subject payments in a different room (so no experiment knew whether any individual subject accepted the bonus payment offer). The payments were sealed in an envelope, with the cash payments wrapped in a thick debriefing handout so that subjects could not tell how much each had been paid. This was important to ensure that subjects could not be identified as having accepted a bonus payment offer based on the thickness of the payment envelope.

Subjects were then called to the front of the room, were paid by providing their chit with the subject number on it in exchange for the payment envelope, and were sent out of the lab into a waiting bus - there were no opportunities for subjects who had completed the study to communicate with subjects who had not yet participated. As soon as all subjects were paid and had exited, the subsequent session began immediately.

\subsection{Empirical Analysis}

2.2.1. Sample Characteristics and Balance Across Conditions. Table 1, column 1, presents the characteristics of our experimental sample. One can see that all of our participants were men, which was by design. In addition, participants were, on average, young and relatively well-educated. The latter is again by design, as literacy was required to implement our study. Around one half of the subjects were engaged in some economic activity at the time of the study. Around two-thirds of subjects were Pashtun, 10 percent Punjabi, and another 10 percent Baloch. Around 85\% are Sunni Muslims. The bottom row of Table 1 displays the sample sizes in each treatment cell, and columns 2-9 of Table 1 present the characteristics of subjects across experimental conditions. We find that respondent characteristics, including demographics, education levels, and Big 5 personality traits are balanced across conditions (see Table 1, column 10). 
TABLE 1. Summary statistics and covariates balance in Experiment 1.

\begin{tabular}{|c|c|c|c|c|c|c|c|c|c|c|}
\hline & \multirow{3}{*}{$\begin{array}{c}\text { Full } \\
\text { Sample } \\
\text { (1) }\end{array}$} & \multicolumn{4}{|c|}{ LUMS } & \multicolumn{4}{|c|}{ U.S. government } & \multirow{3}{*}{$\begin{array}{c}p \text {-value } \\
(10)\end{array}$} \\
\hline & & \multicolumn{2}{|c|}{ Low payment } & \multicolumn{2}{|c|}{ High payment } & \multicolumn{2}{|c|}{ Low payment } & \multicolumn{2}{|c|}{ High payment } & \\
\hline & & $\begin{array}{l}\text { Pri } \\
(2)\end{array}$ & $\begin{array}{l}\text { Pub } \\
\text { (3) }\end{array}$ & $\begin{array}{l}\text { Pri } \\
(4)\end{array}$ & $\begin{array}{c}\text { Pub } \\
(5)\end{array}$ & $\begin{array}{l}\text { Pri } \\
(6)\end{array}$ & $\begin{array}{l}\text { Pub } \\
\text { (7) }\end{array}$ & $\begin{array}{l}\text { Pri } \\
(8)\end{array}$ & $\begin{array}{l}\text { Pub } \\
\text { (9) }\end{array}$ & \\
\hline $\begin{array}{l}\text { Currently engaged } \\
\text { in economic activity? }\end{array}$ & $\begin{array}{c}0.504 \\
(0.500)\end{array}$ & $\begin{array}{c}0.468 \\
{[0.045]}\end{array}$ & $\begin{array}{c}0.489 \\
{[0.039]}\end{array}$ & $\begin{array}{c}0.518 \\
{[0.042]}\end{array}$ & $\begin{array}{c}0.489 \\
{[0.048]}\end{array}$ & $\begin{array}{c}0.500 \\
{[0.046]}\end{array}$ & $\begin{array}{c}0.529 \\
{[0.040]}\end{array}$ & $\begin{array}{c}0.521 \\
{[0.043]}\end{array}$ & $\begin{array}{c}0.518 \\
{[0.041]}\end{array}$ & 0.96 \\
\hline Age & $\begin{array}{l}23.7 \\
(5.0)\end{array}$ & $\begin{array}{l}23.2 \\
{[0.5]}\end{array}$ & $\begin{array}{l}23.6 \\
{[0.5]}\end{array}$ & $\begin{array}{l}23.6 \\
{[0.5]}\end{array}$ & $\begin{array}{l}24.2 \\
{[0.5]}\end{array}$ & $\begin{array}{l}23.3 \\
{[0.5]}\end{array}$ & $\begin{array}{l}23.8 \\
{[0.5]}\end{array}$ & $\begin{array}{l}24.2 \\
{[0.4]}\end{array}$ & $\begin{array}{l}23.6 \\
{[0.5]}\end{array}$ & 0.35 \\
\hline Single & $\begin{array}{c}0.692 \\
(0.462)\end{array}$ & $\begin{array}{c}0.696 \\
{[0.039]}\end{array}$ & $\begin{array}{c}0.691 \\
{[0.034]}\end{array}$ & $\begin{array}{c}0.691 \\
{[0.047]}\end{array}$ & $\begin{array}{c}0.683 \\
{[0.042]}\end{array}$ & $\begin{array}{c}0.748 \\
{[0.037]}\end{array}$ & $\begin{array}{c}0.669 \\
{[0.044]}\end{array}$ & $\begin{array}{c}0.674 \\
{[0.037]}\end{array}$ & $\begin{array}{c}0.684 \\
{[0.048]}\end{array}$ & 0.79 \\
\hline Years of education & $\begin{array}{l}11.9 \\
(2.8)\end{array}$ & $\begin{array}{l}12.1 \\
{[0.2]}\end{array}$ & $\begin{array}{l}11.9 \\
{[0.3]}\end{array}$ & $\begin{array}{l}11.8 \\
{[0.2]}\end{array}$ & $\begin{array}{l}11.7 \\
{[0.2]}\end{array}$ & $\begin{array}{l}12.1 \\
{[0.3]}\end{array}$ & $\begin{array}{l}11.5 \\
{[0.3]}\end{array}$ & $\begin{array}{l}11.7 \\
{[0.3]}\end{array}$ & $\begin{array}{c}12.0 \\
{[0.2]}\end{array}$ & 0.56 \\
\hline $\begin{array}{l}\text { Ethnic groups } \\
\text { Punjabi }\end{array}$ & $\begin{array}{c}0.101 \\
(0.301)\end{array}$ & $\begin{array}{c}0.090 \\
{[0.029]}\end{array}$ & $\begin{array}{c}0.098 \\
{[0.032]}\end{array}$ & $\begin{array}{c}0.096 \\
{[0.029]}\end{array}$ & $\begin{array}{c}0.104 \\
{[0.037]}\end{array}$ & $\begin{array}{c}0.101 \\
{[0.033]}\end{array}$ & $\begin{array}{c}0.093 \\
{[0.036]}\end{array}$ & $\begin{array}{c}0.119 \\
{[0.029]}\end{array}$ & $\begin{array}{c}0.105 \\
{[0.034]}\end{array}$ & 0.95 \\
\hline Pashtun & $\begin{array}{c}0.641 \\
(0.480)\end{array}$ & $\begin{array}{c}0.634 \\
{[0.067]}\end{array}$ & $\begin{array}{c}0.632 \\
{[0.067]}\end{array}$ & $\begin{array}{c}0.640 \\
{[0.069]}\end{array}$ & $\begin{array}{c}0.634 \\
{[0.070]}\end{array}$ & $\begin{array}{c}0.643 \\
{[0.067]}\end{array}$ & $\begin{array}{c}0.667 \\
{[0.065]}\end{array}$ & $\begin{array}{c}0.622 \\
{[0.065]}\end{array}$ & $\begin{array}{c}0.654 \\
{[0.067]}\end{array}$ & 0.75 \\
\hline Baluchi & $\begin{array}{c}0.091 \\
(0.288)\end{array}$ & $\begin{array}{c}0.082 \\
{[0.029]}\end{array}$ & $\begin{array}{c}0.120 \\
{[0.042]}\end{array}$ & $\begin{array}{c}0.103 \\
{[0.035]}\end{array}$ & $\begin{array}{c}0.067 \\
{[0.028]}\end{array}$ & $\begin{array}{c}0.093 \\
{[0.032]}\end{array}$ & $\begin{array}{c}0.093 \\
{[0.037]}\end{array}$ & $\begin{array}{c}0.096 \\
{[0.033]}\end{array}$ & $\begin{array}{c}0.075 \\
{[0.024]}\end{array}$ & 0.77 \\
\hline Urdu & $\begin{array}{c}0.017 \\
(0.129)\end{array}$ & $\begin{array}{c}0.007 \\
{[0.007]}\end{array}$ & $\begin{array}{c}0.015 \\
{[0.011]}\end{array}$ & $\begin{array}{c}0.015 \\
{[0.010]}\end{array}$ & $\begin{array}{c}0.037 \\
{[0.019]}\end{array}$ & $\begin{array}{c}0.008 \\
{[0.008]}\end{array}$ & $\begin{array}{c}0.016 \\
{[0.011]}\end{array}$ & $\begin{array}{c}0.022 \\
{[0.013]}\end{array}$ & $\begin{array}{l}0.015 \\
{[0.011]}\end{array}$ & 0.69 \\
\hline Seraiki & $\begin{array}{l}0.106 \\
(0.308)\end{array}$ & $\begin{array}{c}0.127 \\
{[0.039]}\end{array}$ & $\begin{array}{c}0.075 \\
{[0.028]}\end{array}$ & $\begin{array}{c}0.132 \\
{[0.033]}\end{array}$ & $\begin{array}{c}0.142 \\
{[0.041]}\end{array}$ & $\begin{array}{c}0.116 \\
{[0.037]}\end{array}$ & $\begin{array}{c}0.085 \\
{[0.030]}\end{array}$ & $\begin{array}{c}0.089 \\
{[0.029]}\end{array}$ & $\begin{array}{c}0.083 \\
{[0.024]}\end{array}$ & 0.66 \\
\hline $\begin{array}{l}\text { Religion } \\
\text { Shia }\end{array}$ & $\begin{array}{c}0.053 \\
(0.224)\end{array}$ & $\begin{array}{c}0.037 \\
{[0.019]}\end{array}$ & $\begin{array}{c}0.045 \\
{[0.021]}\end{array}$ & $\begin{array}{c}0.083 \\
{[0.029]}\end{array}$ & $\begin{array}{c}0.060 \\
{[0.025]}\end{array}$ & $\begin{array}{c}0.040 \\
{[0.017]}\end{array}$ & $\begin{array}{c}0.076 \\
{[0.025]}\end{array}$ & $\begin{array}{c}0.045 \\
{[0.020]}\end{array}$ & $\begin{array}{c}0.038 \\
{[0.019]}\end{array}$ & 0.58 \\
\hline Sunni & $\begin{array}{c}0.853 \\
(0.354)\end{array}$ & $\begin{array}{c}0.844 \\
{[0.033]}\end{array}$ & $\begin{array}{c}0.841 \\
{[0.033]}\end{array}$ & $\begin{array}{c}0.812 \\
{[0.037]}\end{array}$ & $\begin{array}{c}0.851 \\
{[0.032]}\end{array}$ & $\begin{array}{c}0.849 \\
{[0.034]}\end{array}$ & $\begin{array}{c}0.855 \\
{[0.033]}\end{array}$ & $\begin{array}{c}0.895 \\
{[0.028]}\end{array}$ & $\begin{array}{c}0.880 \\
{[0.029]}\end{array}$ & 0.63 \\
\hline Muslim - other & $\begin{array}{c}0.087 \\
(0.282)\end{array}$ & $\begin{array}{c}0.119 \\
{[0.028]}\end{array}$ & $\begin{array}{c}0.106 \\
{[0.027]}\end{array}$ & $\begin{array}{c}0.098 \\
{[0.028]}\end{array}$ & $\begin{array}{c}0.082 \\
{[0.022]}\end{array}$ & $\begin{array}{c}0.103 \\
{[0.027]}\end{array}$ & $\begin{array}{c}0.069 \\
{[0.024]}\end{array}$ & $\begin{array}{c}0.053 \\
{[0.018]}\end{array}$ & $\begin{array}{c}0.068 \\
{[0.021]}\end{array}$ & 0.41 \\
\hline Big 5 & & & & & & & & & & \\
\hline Openness to experience & $\begin{array}{c}3.020 \\
(0.424)\end{array}$ & $\begin{array}{c}3.062 \\
{[0.033]}\end{array}$ & $\begin{array}{c}3.072 \\
{[0.044]}\end{array}$ & $\begin{array}{c}2.998 \\
{[0.037]}\end{array}$ & $\begin{array}{c}3.014 \\
{[0.036]}\end{array}$ & $\begin{array}{c}3.021 \\
{[0.036]}\end{array}$ & $\begin{array}{c}3.015 \\
{[0.035]}\end{array}$ & $\begin{array}{c}2.990 \\
{[0.033]}\end{array}$ & $\begin{array}{c}2.985 \\
{[0.025]}\end{array}$ & 0.41 \\
\hline Conscientiousness & $\begin{array}{c}4.110 \\
(0.563)\end{array}$ & $\begin{array}{c}4.110 \\
{[0.056]}\end{array}$ & $\begin{array}{c}4.101 \\
{[0.053]}\end{array}$ & $\begin{array}{c}4.110 \\
{[0.043]}\end{array}$ & $\begin{array}{c}4.121 \\
{[0.046]}\end{array}$ & $\begin{array}{c}4.095 \\
{[0.056]}\end{array}$ & $\begin{array}{c}4.124 \\
{[0.046]}\end{array}$ & $\begin{array}{c}4.064 \\
{[0.042]}\end{array}$ & $\begin{array}{c}4.157 \\
{[0.053]}\end{array}$ & 0.88 \\
\hline Extraversion & $\begin{array}{c}3.590 \\
(0.512)\end{array}$ & $\begin{array}{c}3.655 \\
{[0.046]}\end{array}$ & $\begin{array}{c}3.586 \\
{[0.048]}\end{array}$ & $\begin{array}{c}3.572 \\
{[0.038]}\end{array}$ & $\begin{array}{c}3.564 \\
{[0.044]}\end{array}$ & $\begin{array}{c}3.543 \\
{[0.047]}\end{array}$ & $\begin{array}{c}3.543 \\
{[0.047]}\end{array}$ & $\begin{array}{c}3.566 \\
{[0.039]}\end{array}$ & $\begin{array}{c}3.689 \\
{[0.040]}\end{array}$ & 0.17 \\
\hline Agreeableness & $\begin{array}{c}3.805 \\
(0.566)\end{array}$ & $\begin{array}{c}3.812 \\
{[0.044]}\end{array}$ & $\begin{array}{c}3.848 \\
{[0.055]}\end{array}$ & $\begin{array}{c}3.792 \\
{[0.048]}\end{array}$ & $\begin{array}{c}3.740 \\
{[0.047]}\end{array}$ & $\begin{array}{c}3.785 \\
{[0.051]}\end{array}$ & $\begin{array}{c}3.835 \\
{[0.050]}\end{array}$ & $\begin{array}{c}3.797 \\
{[0.051]}\end{array}$ & $\begin{array}{c}3.829 \\
{[0.050]}\end{array}$ & 0.83 \\
\hline Neuroticism & $\begin{array}{c}2.901 \\
(0.530)\end{array}$ & $\begin{array}{c}2.902 \\
{[0.062]}\end{array}$ & $\begin{array}{c}2.919 \\
{[0.038]}\end{array}$ & $\begin{array}{c}2.952 \\
{[0.039]}\end{array}$ & $\begin{array}{c}2.869 \\
{[0.043]}\end{array}$ & $\begin{array}{c}2.898 \\
{[0.042]}\end{array}$ & $\begin{array}{c}2.911 \\
{[0.039]}\end{array}$ & $\begin{array}{c}2.880 \\
{[0.055]}\end{array}$ & $\begin{array}{c}2.876 \\
{[0.048]}\end{array}$ & 0.73 \\
\hline Number of observations & 1152 & 144 & 144 & 144 & 144 & 144 & 144 & 144 & 144 & \\
\hline
\end{tabular}

Note: Column 1 presents the mean for each variable based on our sample of 1,152 subjects. The Big 5 characteristics were recorded on a 1 to 5 Likert scale. Standard deviations are in parentheses. Columns 2 to 10 report the mean level of each variable, with standard errors clustered at session level in brackets, for each treatment cell. For each variable, column 10 reports the $p$-value of a joint test that the mean levels are the same for all treatment cells (columns 2-9). The last row presents the number of observations in each treatment condition. Some calculations used a smaller sample size due to missing information. The proportion of subjects with missing information for each variable is never greater than $8 \%$. The ethnic group categories do not sum to one because of a few small omitted categories (e.g., subjects identifying as Seraiki speakers) and non-response to this question. 
2.2.2. The Expression of Political Identity. We begin by examining rejection rates among subjects offered a 100 Rs. bonus payment in the "private" condition. $25.2 \%$ of subjects offered 100 Rs. from the U.S. government in the private condition choose to reject it. It may be that some of these subjects would have rejected money from any funding agency, not only from the U.S. government. To account for this, we difference out the rejection rate among subjects offered 100 Rs. from LUMS. Only $8.4 \%$ of individuals offered 100 Rs. from LUMS in the private condition choose to reject payment. We thus estimate that the proportion of subjects who rejected the U.S. offer, but would have accepted an offer from LUMS, is $16.8 \%(p<0.001)$; we report these results in row one of Table 2, Panel A. ${ }^{17}$ In Appendix Table A.1, we report the corresponding difference from a regression including session fixed effects and all of the covariates reported in Table 1 . The estimates remain virtually unchanged, consistent with successful implementation of the laboratory protocol across rounds and experimental sites.

17. It is worth noting that $16.8 \%$ may be a lower bound on the fraction of people who are anti-American, as some of those rejecting the LUMS offer might be anti-American as well. LUMS has an international orientation, and is patterned after universities in the United States. Given this, subjects may associate LUMS with the United States, biasing our results toward finding less anti-Americanism when comparing U.S. rejection rates to LUMS rejection rates. 
TABLE 2. Rejection rates in Experiment 1.

\begin{tabular}{|c|c|c|c|}
\hline & \multicolumn{2}{|c|}{ Offer } & \multirow{2}{*}{$\begin{array}{c}\text { Difference } \\
\text { (U.S. Gov't - LUMS) } \\
\text { (3) }\end{array}$} \\
\hline & $\begin{array}{l}\text { U.S. Gov't } \\
\text { (1) }\end{array}$ & $\begin{array}{l}\text { LUMS } \\
\text { (2) }\end{array}$ & \\
\hline \multicolumn{4}{|c|}{ Panel A: low payment } \\
\hline Private & $\begin{array}{c}0.252 \\
{[0.042]}\end{array}$ & $\begin{array}{c}0.084 \\
{[0.021]}\end{array}$ & $\begin{array}{c}0.168 * * * \\
{[0.047]}\end{array}$ \\
\hline Public & $\begin{array}{c}0.170 \\
{[0.026]}\end{array}$ & $\begin{array}{c}0.111 \\
{[0.027]}\end{array}$ & $\begin{array}{l}0.059 * \\
{[0.036]}\end{array}$ \\
\hline $\begin{array}{l}\text { Difference } \\
\text { (private - public) }\end{array}$ & $\begin{array}{l}0.082^{*} \\
{[0.049]}\end{array}$ & $\begin{array}{c}-0.027 \\
{[0.033]}\end{array}$ & $\begin{array}{c}0.109^{* *} \\
{[0.053]}\end{array}$ \\
\hline \multicolumn{4}{|c|}{ Panel B: high payment } \\
\hline Private & $\begin{array}{c}0.097 \\
{[0.031]}\end{array}$ & $\begin{array}{c}0.056 \\
{[0.018]}\end{array}$ & $\begin{array}{c}0.041 \\
{[0.036]}\end{array}$ \\
\hline Public & $\begin{array}{c}0.148 \\
{[0.030]}\end{array}$ & $\begin{array}{c}0.097 \\
{[0.028]}\end{array}$ & $\begin{array}{c}0.051 \\
{[0.041]}\end{array}$ \\
\hline $\begin{array}{l}\text { Difference } \\
\text { (private - public) }\end{array}$ & $\begin{array}{c}-0.051 \\
{[0.032]}\end{array}$ & $\begin{array}{c}-0.041 \\
{[0.032]}\end{array}$ & $\begin{array}{l}-0.010 \\
{[0.051]}\end{array}$ \\
\hline Private & $\begin{array}{c}\text { differences } \\
0.155^{* * *} \\
{[0.045]}\end{array}$ & $\begin{array}{l}\text { ment - hi } \\
0.028 \\
{[0.028]}\end{array}$ & $\begin{array}{c}0.127 * * * \\
{[0.048]}\end{array}$ \\
\hline Public & $\begin{array}{c}0.022 \\
{[0.040]}\end{array}$ & $\begin{array}{c}0.014 \\
{[0.040]}\end{array}$ & $\begin{array}{c}0.008 \\
{[0.054]}\end{array}$ \\
\hline $\begin{array}{l}\text { Difference } \\
\text { (private - public) }\end{array}$ & $\begin{array}{c}0.132 * * \\
{[0.061]}\end{array}$ & $\begin{array}{c}0.014 \\
{[0.045]}\end{array}$ & $\begin{array}{c}0.119 \\
{[0.075]}\end{array}$ \\
\hline
\end{tabular}

Note: Panel A presents rejection rates in the low payment condition for each combination of offer $\times$ privacy condition, and differences in rejection rates depending on offer and privacy conditions. Panel B presents the same information for the high payment condition. Panel $\mathrm{C}$ presents differences for each cell between the low and high payment conditions. Standard errors clustered at the session level are presented in brackets. For differences in rejection rates, we denote: * significant at $10 \%$; ** significant at $5 \%$; *** significant at $1 \%$.

2.2.3. The Role of Social Context: Self- vs. Social Image Concerns . We next investigate the role of social context. Identity considerations might make antiAmericans more likely to reject in public, as this public affirmation of identity might be more important than private preservation of self-image. Anti-Americans with extreme views might also pressure moderates into rejecting the payment in public. Either of these possibilities would produce more rejection in the public condition than in the private. On the other hand, conformity to the majority action of accepting payment would produce less rejection in the public condition.

Examining the raw rejection rates across conditions, we find that $17 \%$ of subjects reject 100 Rs. U.S. government offer in the public condition. This 8.2 percentage points 
lower rejection rate than in the private condition is marginally statistically significant ( $p=0.10$; refer to results presented in Table 2, Panel A, column 1).

Subjects' decisions of whether to accept the bonus payment offer might differ between the public and private conditions even in the absence of any effect of the social environment on the expression of political ideology, per se. For example, one may be less likely to reject the bonus payment offer in the public condition out of concern that one will appear ungrateful or foolish. On the other hand, one may be more likely to reject the payment offer in the public condition if one were concerned about being publicly identified as having just received a large payment. These effects of the public condition in our study would exist irrespective of the identity of the funding agency.

We study these generic effects of the public condition on rejection rates by considering the public versus private difference in rejection rates for subjects who received a 100 Rs. offer from LUMS. In fact, the difference between the public and private rejection rates of the 100 Rs. LUMS offer was quite small-an increase in rejection of 2.7 percentage points — and not statistically significant ( $p=0.412$; refer to results presented in Table 2, Panel A, column 2). The higher rejection rates in public for the LUMS offer suggests that the lower public rejection rates we found for the U.S. offer were not a result of a general reduction in rejection rates when choices are made publicly.

To isolate the effect of (anticipated) public expression on the willingness to express political ideology, we calculate the public versus private difference in rejection rates of the U.S. offer, after differencing out the public and private rejection rates for the LUMS offer. We now estimate a 10.9 percentage point lower rejection rate for the U.S. government offer in the public condition compared to the private condition ( $p=0.047$; refer to the bottom-right entry presented in Table 2, Panel A). In Appendix Table A.1, we report the corresponding difference in differences from a regression including session fixed effects and all of the covariates reported in Table 1 and our findings are very similar. The direction of the effect of anticipated social incentives, in the context of our study, is toward moderation: fewer subjects rejected the U.S. offer when they believed their choice would be made public to other participants.

If anti-American subjects moderate the public expression of their political views out of a desire to conform to the (perceived) majority attitude, then they should correctly perceive that they are in the minority. We measure subjects' beliefs about other subjects' willingness to accept the bonus payment after they decide whether to accept a bonus. The third envelope in the experiment (immediately after the bonus offer) includes an incentivized elicitation of individuals' beliefs about the number of other participants in the room (from 0 to 23) who accept the bonus payment offer (all sessions included exactly 24 participants). Importantly, respondents who reject the U.S. government offer correctly view themselves as belonging to a minority: among respondents who reject the 100 Rs. U.S. offer in private, the average guess was that 
$62.1 \%$ (median $87 \%$ ) of other respondents accepted the offer (we can statistically reject that the average fraction guessed is less than $50 \%$ at a $p$-value of 0.039$).{ }^{18}$

Another analysis suggests itself in evaluating the role of beliefs about others in the higher rejection rate observed in the public condition. If the anticipated observability of the decision does not effect subjects' stated beliefs about the number of individuals who rejected the payment, then the average beliefs of individuals who reject the bonus payment in public will differ from the average beliefs of individuals who reject the bonus payment in private only due to selection. ${ }^{19}$ If individuals who would have rejected in private choose not to reject in public (at least in part) because they have relatively high beliefs about others' acceptance of the payment, then one would expect selection out of rejecting the public offer by high-acceptance beliefs subjects. This selection would produce average beliefs about others' acceptance among individuals who reject the bonus payment in public that are lower than average beliefs about others' acceptance among individuals who reject the bonus payment in private. Indeed, we find that among individuals who reject the bonus payment in private, the average belief is that $62 \%$ of other subjects will accept the bonus payment; among individuals who reject the bonus payment in public, the average belief is just $50 \%(p=0.243)$. Taking these numbers at face value, if we assume that all subjects who reject in public would also reject in private, then we estimate that those who reject in private but conform and accept in public believe that $87.5 \%$ of the subjects accept the offer. ${ }^{20}$

2.2.4. Sensitivity of Political Expression to Payment Size. We next ask: how sensitive is the expression of ideology to the financial cost of that expression? To answer this question, we exploit the random assignment of bonus payments of both 100Rs. and 500 Rs. The rejection rate of the 500 Rs. U.S. offer (in the private condition) is just $9.7 \%$ (reported in row 1, column 1, of Table 2, Panel B). This is a decline in the rejection rate of 15.5 percentage points, from $25.2 \%$ to $9.7 \%$ ( $p<0.001)$, relative to the 100 Rs. private condition offer from the U.S. government (the difference is reported in row 1, column 1 of Table 2, Panel C).

18. It is worth noting that subjects exhibit some projection bias, with individuals who reject the 100 Rs. U.S. offer in private guessing that a significantly smaller fraction of other subjects would accept payment than individuals who accept the offer $(p<0.01)$.

19. Consistent with subjects' guesses about others' decisions being unaffected by the public or private condition, we find very similar average guesses in the two conditions. On average, subjects in the public condition guessed that $80 \%$ of the others would accept the offer, while those in the private condition guessed that $77 \%$ would accept the offer. The $p$-value of the difference is 0.44 .

20. Under this assumption, and considering that the public treatment does not have a direct effect on beliefs, then

$\mathbb{E}[$ belief $\mid$ reject in private $]=\operatorname{Pr}($ reject in public $\mid$ reject in private $) \mathbb{E}[$ belief $\mid$ reject in public $]$

$+\operatorname{Pr}($ accept in public|reject in private $) \mathbb{E}$ [belief|accept in public, but reject in private].

Since we estimate $\quad \mathbb{E}[$ belief $\mid$ reject in private $]=62 \%, \mathbb{E}[$ belief $\mid$ reject in public $]=50 \%, \quad$ and $\operatorname{Pr}($ reject in public|reject in private $)=17 / 25$, we estimate $\mathbb{E}[$ belief $\mid$ accept in public, but reject in private $]=$ $87.5 \%$. 
Examining subjects' rejection of the LUMS bonus payment offer, we find a 2.8 percentage point reduction in rejection rates comparing the (private) 100 Rs. and 500 Rs. offers (reported in row 1, column 2, of Table 2, Panel C). Differencing out the change in the LUMS rejection rate across bonus payment size conditions, we find a reduction in rejection of the U.S. government offer of 12.7 percentage points ( $p=0.01$; refer to row 1, column 3, of Table 2, Panel C). In Appendix Table A.1, we report the corresponding difference in differences from a regression including session fixed effects and all of the covariates reported in Table 1 and results are nearly unchanged. Finally, we present the triple difference: U.S 100 Rs. vs. 500 Rs. offers, public vs. private, U.S. offer vs. LUMS: this is 12.7 percentage points (albeit not statistically significant; refer to the bottom-right entry presented in Table 2, Panel C).

\section{Experiment 2}

\subsection{Design and Implementation}

Between September 19 and October 21, 2015, we ran a second experiment in a new location: the areas surrounding Lahore. This experiment allows us to: (i) address questions about replicability and external validity and (ii) test whether our methodology can be implemented not only in a group/laboratory setting, but also in a door-to-door survey. A third aim of Experiment 2 was to link rejection of the bonus payment offer to an individual's actual political party affiliation - in particular, affiliation with a political party that is strongly anti-American. Because party membership rates were very limited, however, this dimension of the experiment was severely underpowered, and we relegate the results to Appendix Table A.2. ${ }^{21}$ Experiment 2 was implemented in two stages, which appeared, from a subject's perspective, to be unrelated, and which were conducted by two different survey teams. ${ }^{22}$ In the first stage, a door-to-door survey measured subjects' political affiliations; in the second stage, a tablet-based experiment (again based on door-todoor recruiting) elicited intrinsic anti-American ideology.

3.1.1. Context. Experiment 2 was implemented in the lead up to the first election under a new local government system in Punjab, Pakistan. Elections for local government bodies were held in Lahore ten days after the conclusion of our experiment, on October 31, 2015, with the two largest parties in Pakistan, Pakistan Muslim League

21. One can see that rejecting the U.S. government bonus payment offer is weakly positively associated with membership in the anti-American PTI party (and negatively associated with membership in the mainstream PML-N party). Rejection of the offer is very weakly negatively associated with sign-up for the PTI, and very weakly negatively associated with sign-up for the PML-N.

22. It must be noted that the differentiation between the two stages was imperfect, as the consent materials in both mentioned the same contact personnel. Perceptive subjects might thus have linked the two stages. 
(Nawaz League), or PML-N, and Pakistan Tehreek-i-Insaf, or PTI, expected to have a competitive contest.

PML-N is a party typically associated with large-scale infrastructure programs. PML-N refers to infrastructure spending as the 'hallmark priority for PML(N)' in its party manifesto. ${ }^{23}$ PTI, in contrast, contested the 2013 elections on a strong anticorruption and anti-American (put in terms of anti-"war on terror") platform. Its manifesto argues that Pakistan should "not fight others' wars or act as a surrogate for power. [Pakistan] has been subjected to the will of external powers with the most recent involvement in the U.S.-led war on terror which has created polarized and often violent cleavages within Pakistan's polity." 24

3.1.2. Timeline and Site Selection. The experiment was conducted in four neighborhoods of the city of Lahore between September 19th and October 21st, 2015, with the first stage running through October 6th, and the second stage starting on October 8th. The neighborhoods were selected according to two criteria: first, they needed to have large enough populations to provide a sample size of around 2,000 people in the first stage of fieldwork. Second, they needed to be areas with mixed political affiliations, to provide variation in support for the anti-American, PTI party. Using these criteria to guide us, we conducted fieldwork in Bara Sanda, Chungi Amar Sidu, Shalimar Bagh and Bakr Mandi.

3.1.3. Subject Recruitment and Screening. We contracted the same local survey firm as in Experiment 1 to recruit men aged between 18 and 35 from the targeted neighborhoods. The survey firm employed a strict protocol to ensure that from the perspective of respondents, the two stages of the experiment would appear unrelated. In addition to using different sets of field enumerators in the two stages, and using different methods of collecting answers (paper vs. tablets), different survey company names were used in the two stages. In the first stage, enumerators introduced themselves as belonging to the survey company SEDCO (Socio Economic Development Concerns) Associates, while in the second stage, the new enumerators said that they were from DCS (Development Consultancy Services). Both companies are owned and run by the same organization in Islamabad - as in Experiment 1, we attempted to minimize our use of deception.

Upon engaging a potential household for the first stage of the experiment, enumerators inquired about the presence of men between the ages of 18 and 35 in the household. If there was no one suitable, that household was skipped and the next household was engaged. Once a suitable subject was identified and available, enumerators introduced the study, followed by an exercise to gauge literacy (which was necessary for participation in stage 2 of the experiment).

23. See page 13 at http://www.pmo.gov.pk/documents/manifesto.pdf, last accessed January 26, 2018.

24. PTI Manifesto, 2013 http://www.scribd.com/doc/134950996/PTI-Manifesto-2013, last accessed January 25, 2016. 
The second stage of the experiment was a modified version of Experiment 1 conducted at subjects' houses, on an Android tablet. The major recruitment challenge was to conduct stage 2 with the same respondents in the same households as in the first stage. To ensure that this would be possible, field supervisors kept detailed maps of the neighborhoods for which they were responsible, along with using form IDs, and other information noted on the survey questionnaire from the first stage to assist in matching.

Over the course of the fieldwork in the first stage, enumerators approached 4,000 households, of which 1,530 households did not have a suitable respondent, 479 had a suitable respondent, but refused to be interviewed. In total, 1,991 households were successfully interviewed during the first stage of the intervention. The field team was instructed to match households from stage 1 with a targeted sample of 1,200 subjects for stage 2. In recruiting for the second stage, 1,674 of the 1,991 households were approached, of which 410 respondents were not available at home and 52 refused the survey. This produced a sample of 1,212 respondents who participated in both stages of Experiment 2. As we show below, the respondents successfully contacted and matched at stage 2 are broadly (albeit not perfectly) representative of the full sample of respondents in stage 1 .

3.1.4. The Experiment. The first stage of Experiment 2 simply involved a fiveminute survey at the subject's doorstep. ${ }^{25}$ After checking for subjects' literacy using the exercise described above, enumerators asked a series of questions regarding two major parties: PML-N and PTI. In particular, enumerators asked which of the two parties respondents believed to be more anti-American, and whether respondents were members of either party.

The second stage was modeled after the design in Experiment 1, but modified to allow surveyors to conduct the study at subjects' homes using Android tablets. Subjects were asked to (privately) complete a brief ten-question personality survey. Following this survey, half of the subjects were randomly assigned to be asked direct questions about their views on the U.S. government and U.S. government aid to Pakistan (we call this the stated preference condition, which included 601 participants). The ideology of the other half of the subjects was elicited using the methodology developed in Experiment 1 (we call this the revealed preference condition, which included 611 participants).

Payment in the two conditions was as follows. In the stated preference condition, subjects were paid $100 \mathrm{Rs}$. guaranteed as participation payment. ${ }^{26}$ Subjects were told that in addition to the participation payment, a lottery would determine whether they would receive a payment of up to 200 Rs. (in practice, the additional payment amount

25. All of the study materials for both stages are reproduced in Appendix A3.

26. The aim of the stated preference condition was to allow us to estimate an association between stated preferences and anti-American (PTI) party membership. This could then be compared to the association between our revealed preference measure of anti-Americanism - rejection of the U.S. government bonus payment — and party membership. We find that stated preferences very weakly associate with Party membership. Due to lack of power, we again present these results in the Appendix (see Table A.3). 
was drawn from a lottery assigning equal probabilities to the amounts of 0 Rs., 100 Rs., or 200 Rs.). This means that subjects in the stated preference condition could receive 100 Rs., 200 Rs., or 300 Rs. from participating in the study.

In the revealed preference condition, there was also a 100 Rs. participation payment, as well as the possibility of additional payment to be determined via lottery. In this condition, the lottery amount payment was up to 100 Rs. (in practice, the additional payment amount was drawn from a lottery assigning equal probabilities to the amounts of 0 Rs. or 100 Rs.). In addition to the participation payment and the lottery bonus, subjects in the revealed preference condition were offered a bonus payment from the U.S. government, just as in the private condition of Experiment 1. As in Experiment 1, subjects were asked to check a box indicating whether they accepted or rejected the bonus payment offer, with the language associated with the two check box options identical to that in Experiment 1. In total, subjects in the revealed preference condition who accepted the U.S. government offer could receive 200 Rs. or 300 Rs., while those who rejected the offer could receive 100 Rs. or 200 Rs.

We designed the lottery component of subjects' payment to provide "cover" for a subject's choice of whether to accept the bonus payment offer. At the end of the survey, regardless of the treatment condition, a screen simply told the enumerator the total amount of money the subject should receive. Enumerators would pay the subject without knowing the treatment condition or the lottery payment outcome. Thus, regardless of subjects' choice to accept or reject the bonus payment offer, the survey enumerator who paid the subject would be unaware of whether the subject was even offered a payment from the U.S. government, let alone whether the subject accepted the payment.

Subjects were not provided with complete information about the experimental design; thus, it is important to examine the issue of "cover" from the perspective of subjects in the revealed preference condition. How might subjects' perceptions of imperfect cover (if any) have affected their decisions of whether to accept the U.S. offer? In Experiment 1, we find that anticipated public expression pushed subjects in the direction of accepting the bonus payment - this suggests that (perceived) social pressure would tend to push down rejection rates in Experiment 2 as well. However, the nature of social pressure in Experiment 1 differs from that in Experiment 2: in the former, anticipated social pressure came from both experimenters and other subjects; in the latter, pressure came entirely from the experimenter. One might imagine that experimenter demand effects would particularly push subjects toward payment acceptance, rather than rejection (the experimenter is offering the payment, after all), but we acknowledge that we do not have direct evidence on the effects of (perceived) social pressure in this setting.

\subsection{Empirical Analysis}

3.2.1. Sample Characteristics and Balance Across Conditions. Table 3 presents the mean characteristics of the sample from the two stages of Experiment 2, with the stage 2 sample the subset of the stage 1 subjects who were included in both stages. 
Table 3, column 1 presents the mean values of the same variables in Experiment 1, for comparison. By looking at Table 3, columns 1-3, one can see that, relative to respondents in Experiment 1, subjects in Experiment 2 are older (26 vs. 24), less likely to be single ( $50 \%$ vs. $69 \%$ ), less educated (10 vs. 12 years of education), and more likely to be engaged in an economic activity ( $80 \%$ vs. $50 \%$ ). This indicates that the two samples of young men are somewhat different, besides being drawn from different regions of the country. Examining Table 3, columns 2,3, and 6, we do observe a few statistically significant differences between the subjects contacted in stage one and those successfully recontacted in stage two. These differences, however, do not create any issue for the prediction exercise we present in Appendix Table A.2, beyond an additional concern in terms of external validity. Moreover, comparing the means reported in columns 4-5 indicates that the randomization into two treatments within the second stage of Experiment 2 was successful ( $p$-values in Table 3, column 7). 
TABLE 3. Summary statistics and covariates balance in Experiment 2

\begin{tabular}{|c|c|c|c|c|c|c|c|}
\hline & \multirow[b]{2}{*}{$\begin{array}{l}\text { Experiment } 1 \\
\text { (1) }\end{array}$} & \multicolumn{2}{|c|}{ Experiment 2} & \multicolumn{2}{|c|}{ Stage 2} & \multicolumn{2}{|c|}{$\begin{array}{l}p \text {-value } \\
\text { Column }\end{array}$} \\
\hline & & $\begin{array}{l}\text { Stage } 1 \\
\text { (2) }\end{array}$ & $\begin{array}{l}\text { Stage } 2 \\
\text { (3) }\end{array}$ & $\begin{array}{l}\text { Revealed } \\
\text { Preference } \\
\text { (4) }\end{array}$ & $\begin{array}{l}\text { Stated } \\
\text { View } \\
(5)\end{array}$ & $\begin{array}{l}\text { Co } \\
(2)=(3) \\
(6)\end{array}$ & $\begin{array}{c}(4)=(5) \\
(7)\end{array}$ \\
\hline Currently engaged in economic activity? & $\begin{array}{c}0.504 \\
{[0.015]}\end{array}$ & $\begin{array}{c}0.797 \\
{[0.009]}\end{array}$ & $\begin{array}{c}0.799 \\
{[0.012]}\end{array}$ & $\begin{array}{c}0.791 \\
{[0.016]}\end{array}$ & $\begin{array}{c}0.807 \\
{[0.016]}\end{array}$ & 0.869 & 0.475 \\
\hline Age (Years) & $\begin{array}{l}23.7 \\
{[0.2]}\end{array}$ & $\begin{array}{l}26.5 \\
{[0.1]}\end{array}$ & $\begin{array}{l}26.4 \\
{[0.2]}\end{array}$ & $\begin{array}{l}26.2 \\
{[0.2]}\end{array}$ & $\begin{array}{l}26.7 \\
{[0.2]}\end{array}$ & 0.857 & 0.150 \\
\hline Single & $\begin{array}{c}0.692 \\
{[0.014]}\end{array}$ & $\begin{array}{c}0.499 \\
{[0.011]}\end{array}$ & $\begin{array}{c}0.500 \\
{[0.014]}\end{array}$ & $\begin{array}{c}0.514 \\
{[0.020]}\end{array}$ & $\begin{array}{c}0.487 \\
{[0.020]}\end{array}$ & 0.875 & 0.344 \\
\hline Education (Years) & $\begin{array}{l}11.9 \\
{[0.1]}\end{array}$ & $\begin{array}{l}10.0 \\
{[0.1]}\end{array}$ & $\begin{array}{l}10.0 \\
{[0.1]}\end{array}$ & $\begin{array}{l}10.1 \\
{[0.1]}\end{array}$ & $\begin{array}{l}10.0 \\
{[0.1]}\end{array}$ & 0.401 & 0.615 \\
\hline Muslim & $\begin{array}{c}0.993 \\
{[0.002]}\end{array}$ & $\begin{array}{c}0.984 \\
{[0.003]}\end{array}$ & $\begin{array}{c}0.980 \\
{[0.004]}\end{array}$ & $\begin{array}{c}0.975 \\
{[0.006]}\end{array}$ & $\begin{array}{c}0.985 \\
{[0.005]}\end{array}$ & 0.039 & 0.231 \\
\hline $\begin{array}{l}\text { Caste } \\
\text { Rajput }\end{array}$ & - & $\begin{array}{c}0.296 \\
{[0.010]}\end{array}$ & $\begin{array}{c}0.300 \\
{[0.013]}\end{array}$ & $\begin{array}{c}0.308 \\
{[0.019]}\end{array}$ & $\begin{array}{c}0.293 \\
{[0.019]}\end{array}$ & 0.583 & 0.573 \\
\hline Jatt & - & $\begin{array}{c}0.096 \\
{[0.007]}\end{array}$ & $\begin{array}{c}0.100 \\
{[0.009]}\end{array}$ & $\begin{array}{c}0.103 \\
{[0.012]}\end{array}$ & $\begin{array}{c}0.097 \\
{[0.012]}\end{array}$ & 0.518 & 0.702 \\
\hline Mehar & - & $\begin{array}{c}0.065 \\
{[0.006]}\end{array}$ & $\begin{array}{c}0.075 \\
{[0.008]}\end{array}$ & $\begin{array}{c}0.082 \\
{[0.011]}\end{array}$ & $\begin{array}{c}0.068 \\
{[0.010]}\end{array}$ & 0.022 & 0.369 \\
\hline Arain & - & $\begin{array}{c}0.116 \\
{[0.007]}\end{array}$ & $\begin{array}{c}0.107 \\
{[0.009]}\end{array}$ & $\begin{array}{c}0.105 \\
{[0.012]}\end{array}$ & $\begin{array}{c}0.110 \\
{[0.013]}\end{array}$ & 0.158 & 0.776 \\
\hline Other & - & $\begin{array}{c}0.427 \\
{[0.011]}\end{array}$ & $\begin{array}{c}0.417 \\
{[0.014]}\end{array}$ & $\begin{array}{c}0.403 \\
{[0.020]}\end{array}$ & $\begin{array}{c}0.433 \\
{[0.020]}\end{array}$ & 0.290 & 0.290 \\
\hline $\begin{array}{l}\text { Big } 5 \\
\text { Openness to experience }\end{array}$ & $\begin{array}{c}3.020 \\
{[0.013]}\end{array}$ & - & $\begin{array}{c}3.470 \\
{[0.023]}\end{array}$ & $\begin{array}{c}3.427 \\
{[0.032]}\end{array}$ & $\begin{array}{c}3.513 \\
{[0.033]}\end{array}$ & - & 0.059 \\
\hline Conscientiousness & $\begin{array}{l}4.110 \\
{[0.017]}\end{array}$ & - & $\begin{array}{c}3.925 \\
{[0.023]}\end{array}$ & $\begin{array}{c}3.926 \\
{[0.032]}\end{array}$ & $\begin{array}{c}3.923 \\
{[0.032]}\end{array}$ & - & 0.949 \\
\hline Extraversion & $\begin{array}{c}3.590 \\
{[0.015]}\end{array}$ & - & $\begin{array}{c}4.013 \\
{[0.027]}\end{array}$ & $\begin{array}{l}4.000 \\
{[0.039]}\end{array}$ & $\begin{array}{c}4.026 \\
{[0.038]}\end{array}$ & - & 0.638 \\
\hline Agreeableness & $\begin{array}{c}3.805 \\
{[0.017]}\end{array}$ & - & $\begin{array}{c}2.997 \\
{[0.017]}\end{array}$ & $\begin{array}{c}3.016 \\
{[0.023]}\end{array}$ & $\begin{array}{c}2.977 \\
{[0.026]}\end{array}$ & - & 0.256 \\
\hline Neuroticism & $\begin{array}{c}2.901 \\
{[0.016]}\end{array}$ & - & $\begin{array}{c}2.675 \\
{[0.026]}\end{array}$ & $\begin{array}{c}2.656 \\
{[0.037]}\end{array}$ & $\begin{array}{c}2.694 \\
{[0.036]}\end{array}$ & - & 0.470 \\
\hline $\begin{array}{l}\text { Perceive PTI as more able than } \\
\text { PML-N to bring benefits and services } \\
\text { to the community }\end{array}$ & - & $\begin{array}{c}0.504 \\
{[0.011]}\end{array}$ & $\begin{array}{c}0.487 \\
{[0.015]}\end{array}$ & $\begin{array}{c}0.485 \\
{[0.020]}\end{array}$ & $\begin{array}{c}0.488 \\
{[0.021]}\end{array}$ & 0.052 & 0.916 \\
\hline $\begin{array}{l}\text { Perceive PTI as more anti-American } \\
\text { than PML-N }\end{array}$ & - & $\begin{array}{c}0.501 \\
{[0.011]}\end{array}$ & $\begin{array}{c}0.490 \\
{[0.015]}\end{array}$ & $\begin{array}{c}0.484 \\
{[0.020]}\end{array}$ & $\begin{array}{c}0.496 \\
{[0.021]}\end{array}$ & 0.240 & 0.690 \\
\hline $\begin{array}{l}\text { Registered to political party } \\
\text { PTI }\end{array}$ & - & $\begin{array}{c}0.051 \\
{[0.005]}\end{array}$ & $\begin{array}{c}0.045 \\
{[0.006]}\end{array}$ & $\begin{array}{c}0.039 \\
{[0.008]}\end{array}$ & $\begin{array}{c}0.050 \\
{[0.009]}\end{array}$ & 0.129 & 0.370 \\
\hline PML-N & - & $\begin{array}{c}0.062 \\
{[0.005]}\end{array}$ & $\begin{array}{c}0.041 \\
{[0.006]}\end{array}$ & $\begin{array}{c}0.033 \\
{[0.007]}\end{array}$ & $\begin{array}{c}0.050 \\
{[0.009]}\end{array}$ & 0.000 & 0.133 \\
\hline$J_{1}$ & - & $\begin{array}{c}0.012 \\
{[0.002]}\end{array}$ & $\begin{array}{c}0.016 \\
{[0.004]}\end{array}$ & $\begin{array}{c}0.013 \\
{[0.005]}\end{array}$ & $\begin{array}{c}0.018 \\
{[0.005]}\end{array}$ & 0.043 & 0.466 \\
\hline $\begin{array}{l}\text { Interested in signing up with: } \\
\text { PTI }\end{array}$ & - & $\begin{array}{c}0.083 \\
{[0.006]}\end{array}$ & $\begin{array}{c}0.090 \\
{[0.008]}\end{array}$ & $\begin{array}{c}0.080 \\
{[0.011]}\end{array}$ & $\begin{array}{c}0.100 \\
{[0.012]}\end{array}$ & 0.145 & 0.233 \\
\hline PML-N & - & $\begin{array}{c}0.070 \\
{[0.006]}\end{array}$ & $\begin{array}{c}0.079 \\
{[0.008]}\end{array}$ & $\begin{array}{c}0.090 \\
{[0.012]}\end{array}$ & $\begin{array}{c}0.068 \\
{[0.010]}\end{array}$ & 0.034 & 0.160 \\
\hline Registered to vote & - & $\begin{array}{c}0.864 \\
{[0.008]}\end{array}$ & $\begin{array}{c}0.853 \\
{[0.010]}\end{array}$ & $\begin{array}{c}0.852 \\
{[0.014]}\end{array}$ & $\begin{array}{c}0.854 \\
{[0.014]}\end{array}$ & 0.062 & 0.947 \\
\hline Plan to vote & - & $\begin{array}{c}0.928 \\
{[0.006]}\end{array}$ & $\begin{array}{c}0.922 \\
{[0.008]}\end{array}$ & $\begin{array}{c}0.918 \\
{[0.011]}\end{array}$ & $\begin{array}{c}0.925 \\
{[0.011]}\end{array}$ & 0.152 & 0.652 \\
\hline Number of observations & & 1991 & 1212 & 611 & 601 & & \\
\hline
\end{tabular}

Note: Column 1 presents the mean for each variable in the first experiment. Columns 2 and 3 present the mean for each variable respectively in the first and second stage of the second experiment. Columns 4 and 5 present information on subjects from the second stage of the second experiment separately for those in the revealed preference and in the stated view groups. Column 6 presents $p$-values of tests that means are the same for subjects in stage 1 and stage 2 of the second experiment, while column 7 presents $p$-values of tests that means are the same for subjects in the revealed preference and stated view groups. Standard errors are reported in brackets. 
3.2.2. Revealed Preference and Stated Preference Measures of Anti-Americanism. In the second stage of Experiment 2, we find that $34 \%$ of the respondents in the revealed preference condition rejected the 100 Rs., (private) bonus payment offer from the U.S. government (this is reported with standard error in the first row of Table 4, column 2). This number is quite similar to the rejection rate we observed in the 100 Rs., private condition in Experiment 1 (reported with standard error in the first row of Table 4, column 1). The finding in Experiment 2 is valuable both for establishing some degree of external validity of our original finding, and for testing the robustness of our elicitation methodology: it is worth emphasizing that the results in Experiment 2 were found in a different part of Pakistan, with a different sample frame, and a different data collection method.

TABLE 4. Anti-americanism measures - Experiments $1 \& 2$

\begin{tabular}{lcc}
\hline Measure & $\begin{array}{c}\text { Experiment } 1 \\
(1)\end{array}$ & $\begin{array}{c}\text { Experiment } 2 \\
(2)\end{array}$ \\
\hline Rejected Bonus Payment (=1) & 0.252 & 0.342 \\
& {$[0.042]$} & {$[0.019]$} \\
Views U.S. Gov't Negatively (=1) & 0.289 & 0.394 \\
& {$[0.035]$} & {$[0.020]$} \\
Views U.S. Aid Negatively (=1) & 0.271 & 0.309 \\
& {$[0.041]$} & {$[0.019]$} \\
\hline
\end{tabular}

Note: This table presents averages for the three measures of anti-Americanism for experiments 1 and 2. For experiment 1, we consider the sample in the low U.S. government payment, private condition. Standard errors in brackets.

In the stated preference condition of Experiment 2, we ask subjects to report their views on the U.S government overall, and their views on U.S. aid. We find that around $39 \%$ of subjects report negative views of the U.S. government (see row 2 of Table 4, column 2), and that around $31 \%$ of subjects report negative views of U.S. aid (see row 3 of Table 4, column 2). Again, our findings in Experiment 2 are similar to those for identical questions asked in Experiment 1 (compare with Table 4, column 1).

\section{Discussion: Interpreting Rejection of the Bonus Payment Offer}

We next present a simple framework through which we clarify the threats to our interpretation of rejection of the bonus payment offer from the U.S. government as an identity-preserving political expression. Suppose that an individual derives utility from rejecting payment through three channels. First, rejecting payment may provide an individual with utility for instrumental reasons; that is, because expression changes the world in ways that bring utility to the individual. Second, when rejection of the payment is (anticipated to be) observed by others, it might differentially provide utility (or disutility) for social reasons. Finally, the individual might derive utility from rejecting 
the payment for intrinsic reasons: these include political identity, but can also include other intrinsic reasons to reject payment.

\subsection{Consequential Concerns Other Than The Forgone Payment}

We designed our study such that the stakes of rejecting the payment offer would be meaningful for subjects, but trivial for the U.S. government: it is difficult to imagine a meaningful effect on U.S. finances arising from subjects' decisions to reject or accept the bonus payment offer. However, despite the fact that the fiscal stakes for the U.S. government were trivial, subjects may have believed that their choices in aggregate would have meaningful consequences by sending a signal to the U.S. government. While we cannot absolutely rule this out, we note that the median subject who rejected the U.S. bonus payment offer in the 100 Rs., private condition believed (as measured in our incentivized elicitation) that $87 \%$ of the other subjects accepted the offer. Thus, any choice to reject payment would have been perceived to represent a small increment on top of a small minority, rather than contributing to a strong signal of opposition to the U.S. government.

\subsection{Social Concerns}

We next consider the possibility that subjects' choices to reject the bonus payment offer were shaped by social concerns despite our attempts to make their decisions completely private. Even if subjects did consider the possibility that their choices might be observable, there are reasons to believe that this social cost term would have increased the cost of rejecting the U.S. payment offer, making the identitymotivated revealed preference even stronger. First, if subjects were concerned about the observability of their choice by the research team, standard experimenter demand effects would seem to pull in the direction of accepting the payment offer: if a subject is offered a bonus payment, there might be (if anything) implicit pressure to accept this is the primary social pressure at work in Experiment 2, and also may have been at work in Experiment 1. Second, if subjects believed that their choice might be revealed to others, our estimate in Experiment 1 of the effect of anticipated public expression suggests that observability of the choice would again reduce rejection rates.

\subsection{Intrinsic Utility for Reasons other than Anti-American Ideology}

An important concern is that subjects in both experiments might have privately rejected the U.S. bonus payment offer not because they disliked the U.S., but for some other intrinsic reason. For example, perhaps they felt uncomfortable accepting an additional monetary payment. As discussed above, however, we address this concern in our analysis of Experiment 1 by differencing out the private rejection rates from the LUMS offer: we find a substantial fraction of the population rejecting the U.S. government offer beyond those who reject the LUMS offer. 
The U.S. government offer differed from the LUMS offer both in the foreignness of the entity offering the payment, and in the fact that the entity was a government. One might be concerned that the difference in rejection rates between the U.S. payment and the LUMS payment conditions arose from anti-foreign or anti-government views, rather than specifically anti-American views. We can assess this possibility by examining the correlation between rejection of the U.S. offer and stated preferences. As noted above, in Experiment 1, following subjects' decisions of whether to accept the bonus payment, they were asked to answer a number of direct survey questions, which included elicitations of their stated views on: (i) aid provided by the U.S. government, (ii) the U.S. government overall, (iii) aid provided by the Japanese government, and (iv) the Japanese government overall (Japan was picked as a plausibly neutral, rich, foreign nation that is currently engaged in providing funds to Pakistan).

For each of these questions, respondents were asked to express their views by picking a number from 1 to 5 , with 1 corresponding to very negative views, and 5 to very positive views. We convert responses into "negative views" dummy variables equal to 1 if subjects responses were either " 1 " or " 2 ". Subjects were also asked to compare their views on the four aforementioned topics relative to the other participants in the room, also on a scale from 1 to 5; we converted these into analogous "negative relative views" dummy variables.

We regress each of the 8 stated views outcomes on a dummy variable indicating whether subjects rejected the bonus payment in Experiment 1's 100 Rs., private, U.S. offer, condition. In Table 5, columns 1-4, one can see that rejection of the U.S. payment offer is significant associated with absolutely and relatively anti-American stated views. Among individuals who accept the payment offer, around $15 \%$ have negative views of the U.S. government - this jumps to $70 \%$ among those who rejected payment. In contrast, in Table 5, columns 5-8, one can see that rejection of the U.S. payment offer has almost no association with stated views on Japan or Japanese aid. Among individuals who accept the payment offer, around $13 \%$ have negative views of the Japanese government - this is practically unchanged at $17 \%$ among those who rejected payment. These results suggest that the dominant source of intrinsic motivation to reject the U.S. government bonus payment offer was specific to the U.S. Government.

\section{Conclusion}

We show that a significant minority of Pakistani men are willing to forgo a sizable payment simply to avoid checking a box that affirms gratitude toward the U.S. government for providing the funds. The structure of our experiment allows us to go far beyond the (unsurprising) documentation of anti-American sentiment in Pakistan: the behavior is private, and is unlikely to be of significant "real world" consequence, suggesting that rejection of payment is motivated by the need to preserve individuals' sense of self. This is the clearest evidence of which we are aware of the existence of 


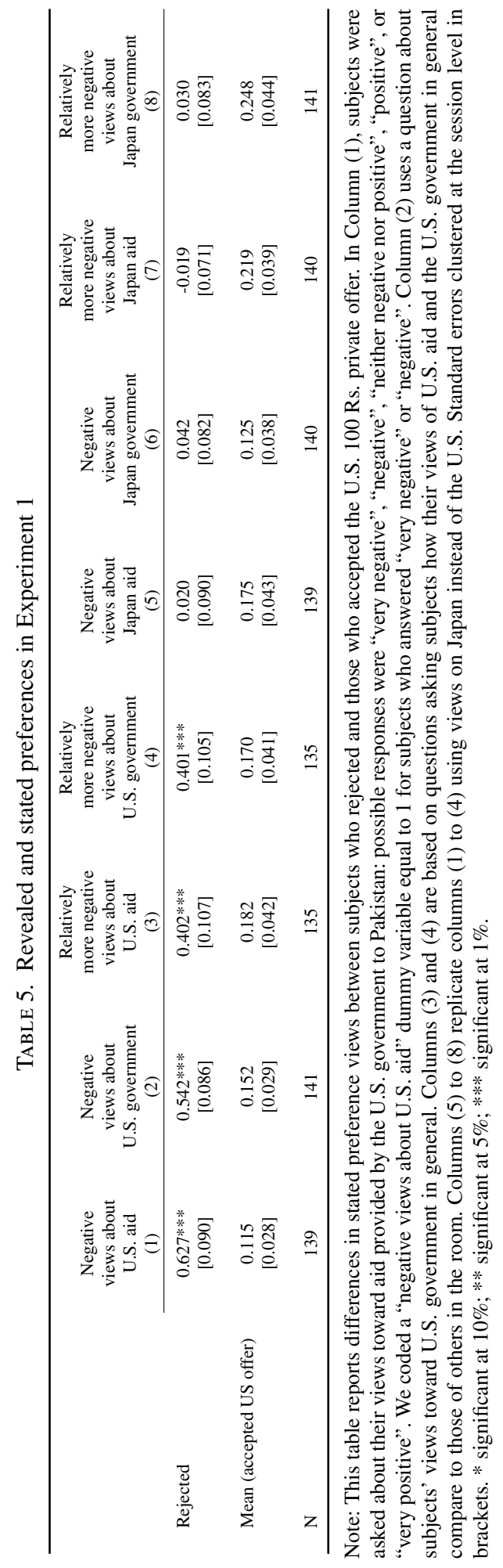


a "political identity," and provides empirical grounding for the inclusion of intrinsic motivation in models of political behavior.

Our work suggests two avenues for further research. One is to understand where political identity comes from, very much related to a large literature on the sources of political attitudes and ideology. ${ }^{27} \mathrm{~A}$ second direction is to evaluate the impact of variation in consequences and in social setting on the real-world expression of individuals' political identities. Our findings suggest that policies aimed at shaping the expression of political attitudes - for example, reducing anti-American political expression - simply by changing instrumental incentives may be limited. But the elasticity of political expression deserves further empirical investigation.

\section{References}

Akerlof, George A. and Rachel E. Kranton (2000). “Economics And Identity.” Quarterly Journal of Economics, 115(3), 715-743.

Andreoni, James (1990). "Impure Altruism and Donations to Public Goods: A Theory of WarmGlow." Economic Journal, 100, 464-477.

Ariely, Dan, Anat Bracha, and Stephan Meier (2009). "Doing Good or Doing Well? Image Motivation and Monetary Incentives in Behaving Prosocially.” American Economic Review, 99(1), 544-555.

Augenblick, Ned, Jesse M. Cunha, Ernesto Dal Bó, and Justin M. Rao (2012). "The Economics of Faith: Using an Apocalyptic Prophecy to Elicit Religious Beliefs in the Field.” NBER Working Paper No. 18641.

Beath, Andrew, Fotini Christia, and Ruben Enikolopov (2012). "Winning Hearts and Minds through Development: Evidence from a Field Experiment in Afghanistan.” MIT Political Science Deparment Working Paper No. 2011-14.

Becker, Gary S. (1957). The Economics of Discrimination. University of Chicago Press.

Bénabou, Roland and Jean Tirole (2003). "Intrinsic and Extrinsic Motivation." Review of Economic Studies, 70(3), 489-520.

Bénabou, Roland and Jean Tirole (2006a). "Belief in a Just World and Redistributive Politics." Quarterly Journal of Economics, 121(2), 699-746.

Bénabou, Roland and Jean Tirole (2006b). "Incentives and Prosocial Behavior." American Economic Review, 96(5), 1652-1678.

Berman, Eli, Michael Callen, Clark Gibson, James D. Long, and Arman Rezaee (2017). "Election Fairness and Government Legitimacy in Afghanistan.” Unpublished, UC-San Diego.

Berman, Eli, Jacob N. Shapiro, and Joseph H. Felter (2011). "Can Hearts and Minds Be Bought? The Economics of Counterinsurgency in Iraq." Journal of Political Economy, 119(4), 766 - 819.

Bernheim, B. Douglas (1994). "A Theory of Conformity." Journal of Political Economy, 102(5), 841-877.

Bisin, Alberto and Thierry Verdier (2001). "The Economics of Cultural Transmission and the Dynamics of Preferences." Journal of Economic Theory, 97(2), 298-319.

Blaydes, Lisa and Drew A Linzer (2012). "Elite competition, religiosity, and anti-Americanism in the Islamic world." American Political Science Review, 106(2), 225-243.

27. This literature has examined, among others, parents' influence (Bisin and Verdier 2001); peer effects (Sacerdote 2001); the role of the media (Strömberg 2004); personal experience (Giuliano and Spilimbergo 2014); education (Cantoni et al. forthcoming); and, a range of fundamental preferences (Cantoni et al. 2016). 
Bordalo, Pedro, Nicola Gennaioli, and Andrei Shleifer (2013). "Salience and Consumer Choice." Journal of Political Economy, 121(5), 803-843.

Brennan, Geoffrey and James Buchanan (1984). "Voter choice: evaluating political alternatives." American Behavioral Scientist, 28, 181-201.

Brennan, Geoffrey and Loren Lomasky (1993). Democracy and Decision: The Pure Theory of Electoral Preference. Cambridge University Press, New York.

Bursztyn, Leonardo and Robert T. Jensen (2015). "How Does Peer Pressure Affect Educational Investments?" Quarterly Journal of Economics, 130(3), 1329-1367.

Cantoni, Davide, Yuyu Chen, David Y. Yang, Noam Yuchtman, and Jane Zhang (forthcoming). "Curriculum and Ideology." Journal of Political Economy.

Cantoni, Davide, David Y. Yang, Noam Yuchtman, and Jane Zhang (2016). "The Fundamental Determinants of Anti-Authoritarianism." Unpublished, UC-Berkeley.

Clingingsmith, David, Asim Ijaz Khwaja, and Michael R. Kremer (2009). "Estimating the impact of the Hajj: Religion and tolerance in Islam's global gathering." Quarterly Journal of Economics, 124(3), 1133-1170.

Cohen, Dov, Richard E. Nesbitt, Brian F. Bowdle, and Norbert Schwarz (1996). "Insult, Aggression, and the Southern Culture of Honor: An 'Experimental Ethnography'.' Journal of Personality and Social Psychology, pp. 945-960.

Corstange, Daniel (2014). "Foreign-Sponsorship Effects in Developing-World Surveys: Evidence from a Field Experiment in Lebanon." Public Opinion Quarterly, 78(2), 474-484.

Delavande, Adeline and Basit Zafar (2012). "How Deeply Held are Anti-American Attitudes among Pakistani Youth? Evidence Using Experimental Variation in Information.”, URL https://papers. ssrn.com/sol3/papers.cfm?abstract_id=2043148. Working Paper.

Dell, Melissa and Pablo Querubin (2017). "Nation building through foreign intervention: Evidence from discontinuities in military strategies." The Quarterly Journal of Economics, 1, 64.

DellaVigna, Stefano, John A. List, and Ulrike Malmendier (2012). "Testing for Altruism and Social Pressure in Charitable Giving." Quarterly Journal of Economics, 127, 1-56.

DellaVigna, Stefano, John A List, Ulrike Malmendier, and Gautam Rao (2016). "Voting to tell others." The Review of Economic Studies, 84(1), 143-181.

Downs, Anthony (1957). An Economic Theory of Democracy. Addison Wesley, New York.

Feddersen, Timothy and Alvaro Sandroni (2006). "A Theory of Participation in Elections." American Economic Review, 96, 1271-1282.

Funk, Patricia (2010). "Social Incentives and Voter Turnout: Evidence from the Swiss Mail Ballot System." Journal of the European Economic Association, 8(5), 1077-1103.

Gentzkow, Matthew A. and Jesse M. Shapiro (2004). "Media, Education, and Anti-Americanism in the Muslim World." Journal of Economic Perspectives, 18(3), 117-133.

Gerber, Alan S., Donald P. Green, and Christopher W. Larimer (2008). "Social Pressure and Voter Turnout: Evidence from a Large-scale Field Experiment." American Political Science Review, 102(1), 33-48.

Gerber, Alan S., Gregory A. Huber, David Doherty, and Conor M. Dowling (2013). "Social Judgments and Political Participation: Estimating the Consequences of Social Rewards and Sanctions for Voting.”, URL https://sites.google.com/site/conordowlingpolsci/SocRetVoting.pdf. Working Paper.

Giuliano, Paola and Antonio Spilimbergo (2014). "Growing Up in a Recession.” Review of Economic Studies, 81(2), 787-817.

Hoffman, Elizabeth, Kevin McCabe, and Vernon L. Smith (1996). "Social Distance and OtherRegarding Behavior in Dictator Games." American Economic Review, 86(3), 653-660.

Jha, Saumitra and Moses Shayo (2017). "Valuing Peace: The Effects of Financial Market Exposure on Votes and Political Attitudes.", URL https://papers.ssrn.com/sol3/papers.cfm?abstract_id= 2716660. Unpublished, Stanford University.

Kamenica, Emir and Louisa Egan Brad (2014). "Voters, dictators, and peons: expressive voting and pivotality." Public Choice, 159, 159-176. 
Ledyard, John O. (1984). "The pure theory of two-candidate elections." Public Choice, 44, 7-41. Milgram, Stanley (1977). The Individual in a Social World: Essays and Experiments. AddisonWesley, Reading, MA.

Palfrey, Thomas R. and Howard Rosenthal (1983). "A Strategic Calculus of Voting." Public Choice, 41(1), 7-53.

Palfrey, Thomas R. and Howard Rosenthal (1985). "Voter Participation and Strategic Uncertainty." American Political Science Review, 79, 67-78.

Raghavarao, Damaraju and Walter T. Federer (1979). "Block Total Response as an Alternative to the Randomized Response Method in Surveys." Journal of the Royal Statistical Society, Series B (Statistical Methodology) 41(1), 40-45.

Rao, Gautam (2019). "Familiarity Does Not Breed Contempt: Generosity, Discrimination, and Diversity in Delhi Schools." American Economic Review, 109(3), 774-809.

Riker, William and Peter Ordeshook (1968). "A Theory of the Calculus of Voting." American Political Science Review, 62, 25-43.

Rosenthal, Robert (1963). "On the Social Psychology of the Psychological Experiment: The Experiment's Hypothesis as Unintended Determinant of Experimental Results." American Scientist, 51, 268-283.

Rosenthal, Robert (1966). Experimenter Effects in Behavioral Research. New York: AppletonCentury-Crofts.

Sacerdote, Bruce I. (2001). "Peer effects with random assignment: Results for Dartmouth roommates." Quarterly Journal of Economics, 116(2), 681-704.

Scheussler, Alex (2000). A Logic of Expressive Choice. Princeton University Press, Princeton, NJ.

Shayo, Moses (2009). "A Model of Social Identity with an Application to Political Economy: Nation, Class, and Redistribution.” American Political Science Review, 103(02), 147-29.

Sniderman, Paul M. and Thomas Piazza (1993). The Scar of Race. Harvard University Press.

Strömberg, David (2004). "Mass Media Competition, Political Competition, and Public Policy." Review of Economic Studies, 71(1), 265-284.

Warner, Stanley L. (1965). "Randomized Response: A Survey Technique for Eliminating Evasive Answer Bias." Journal of the American Statistical Association, 60(309), 63-69. 